\title{
Zatına Mir'at Edindim Zatını: Sevmek Zamanı (1965) Filminin Anlatısal ve Görsel Yaklaşımının Tasavvuf Nazarından İncelemesi
}

Suphi Keskin*

\author{
$\ddot{O} \mathbf{z}$
}

Surete âş̧ı olma temasının Divan şiirinde ilk kez işlenmesine Nizâmî-i Gencevî’nin Husrev ü Şirin (1281) adlı mesnevîsinde rastlanmaktadır. Tasavvufta sevme kavramı öte dünyada olabileceği için fiziki bir yakınlıkla değil, ruhani ve batıni bir anlayışla temsil edilir. Metin Erksan'ın 1965 yılında çektiği Sevmek Zamanı filmi surete âşı olma konusunu ele alışında tasavvufi nazarıla geleneksel Osmanlı edebiyatına yakın durarak dönemi içerisinde münferit ve özgün bir yer işgal eden, gelenekle biçimsel yeniliği harmanladığı bir filmdir. Bu yazıda Sevmek Zamanı filmi, özellikle surete âşık olma teması ekseninde ele alınarak divan şiiri ve tasavvufun nazarından içeriksel, biçimsel ve kurgusal özellikleriyle incelenmiştir.

Anahtar Kelimeler: Sevmek Zamanı, tasavvuf, surete âşık olma, anlatı, biçim.

Okutman, Bilkent Üniversitesi İletişim ve Tasarım Bölümü Medya ve Görsel Çalışmalar Programı, Ankara/Türkiye, suphinesetkeskin@gmail.com, orcid.org/0000-0001-5990-8505 


\title{
An Analysis of Time to Love (1965) According to Its Narrative and Visual Approach from Sufi Perspective
}

\begin{abstract}
Falling in love with semblance theme is first encountered in Divan Literature with Nizâmî-i Gencevî’s Husrev u Şirin (1281) entitled masnawi. According to sufi approach, it is a target that can be achieved in the afterlife, love in the physical world therefore, represents a spiritual and esoteric understanding rather than physical proximity. Metin Erksan's Sevmek Zamanı / Time to Love (1965) entitled movie locates itself as a genuine and discrete example of its era through its proximity to traditional Ottoman theme, falling in love with semblance, in a sufistic approach that combines thematic traditionalism and cinematographic renewal. With the study, Time to Love and its main theme, falling in love with semblance is analyzed through the traditional Ottoman poetry and sufistic approach according to its content, form and editing techniques.
\end{abstract}

Keywords: Time to Love, sufism, falling in love with semblance, narration, form. 


\section{"Vasf-ı Kaddiyle Sözüm Mısra-ı Berceste İdi"': Giriş}

Metin Erksan, Muhsin Ertuğrul'un başını çektiği Tiyatrocular Dönemi olarak kabul edilen dönemin teatral sinemasına karşı durarak Türkiye'de yerli biçim ve içerik üzerine ilk kez kafa yormuş yönetmenlerimizdendir. Sinematografik uygulamaları genel olarak toplumcu-gerçekçi yönelimler içerse de Nijat Özön ${ }^{2}$ tarafından Sinemacılar Dönemi (1950-1970) olarak adlandırılan dönemin Ömer Lütfi Akad, Atıf Yılmaz Batıbeki, Osman F. Seden ve Memduh Ün gibi sinemac1larının yanında ve toplumsal gerçekçilik ile ATÜT sineması tartışmaları arasında, Erksan, özellikle tematik bakımdan farklı filmler ortaya koyabilmiştir. Zeynep Gemuhluoğlu'na göre Sevmek Zamanı (1965) filmi, belki de yönetmenini aşacak biçimde onu geleneğin diline bağlamıştır. Surete âşık olma meselesinin filme yüklediği anlam, zaman vurgusuyla beraber geleneğin sinemaya yansımasını, bu film özelinde düşünmemize kapı aralar.

Resme ve tiyatroya bir türlü 1sınamayan Osmanlı, Divan şiirinin sinema karelerini hatırlatan hareketli imgelerine, Karagöz'e, "imgeler ve hicabat" ilişkisine, perde, 1şık ve gölge oyununa aşina olmasının da etkisiyle, fotoğraf ve sinemayı kolayca benimsemiştir . Sultan II. Abdülhamit'in "elektrikli ve manivelalı aletlere karşı olumsuz tavrı bilinse de Lumiere kardeşlerin sinematografı insanlık açısından yararlı bir alet olarak görülerek ülkeye 1896 yılında giriş yapar" ve İsponek (Sponeck) Birahanesi'nde, Lumiere kardeşlerin gösteriminden hemen iki y1l sonra Osmanlı topraklarında 1897 yılında ilk sinema gösterimi yapılır".

Ülke çapında hızla yaygınlaşsa da Türk sineması görsel ve anlatısal bağlamda kendi estetiğini oluşturamaz. Bir bakıma Türkiye sineması halen kendi imaj rejimini oluşturamamıştır ${ }^{5}$. 90'larda ülkemizde sinemanın durma noktasına geldiği dönemde zuhur eden Derviş Zaim, Nuri Bilge Ceylan ve Reha Erdem gibi kimi münferit örneklere gelene kadar imaj üzerine düşünen yönetmenlerimiz de pek azdır. Sinemamızın kendi anlatı özelliklerini ortaya koyabildiği de tartışmalıdır.

1 Enderunlu Vasıf’tan, Nejat Sefercioğlu, „Divan Şiirinde Musiki ile İlgili Unsurların Kullanılış1“, (T.Y.), „Görüntüleme“: Nisan 21, 2018, s.162, http://turkoloji.cu.edu.tr/ESKI TURK EDEBIYATI/nejat_sefercioglu_divan_siiri_musiki_unsurlar_kullanim.pdf, s.11.

2 Nijat Özön, Türk Sinema Tarihi, 1. bs., İstanbul, Doruk, 1965, s. 60-83.

3 Zeynep Gemuhluoğlu, „Mesnevi‘den Sinemaya Aşk, Suret ve Zaman“, Hayal Perdesi, say1 32, 2013, s. 34-45, „Görüntüleme“: Nisan 21, 2018, http:/www.hayalperdesi.net/haber/ yorum/2667-1-mesneviden-sinemaya-ask-suret-ve-zaman.aspx, s. 34.

4 Ali Özuyar, Türkiye ‘de Gösterilen Illk Filmler, May1s 21, 2014, „Görüntüleme“: Nisan 20, 2018, http://www.tsa.org.tr/tr/yazi/yazidetay/12/turkiye'de-gosterilen-ilk-filmler, para. 5.

5 Ulus Baker, Beyin Ekran, ed. E. Berensel, 4. bs., İstanbul, Birikim, 2017, s. 238. 
Gemuhluoğlu, Virginia Woolf'un erken dönemde sinemanın kendi dilini bulamadığına dair yaptığı eleştirinin yönünü Türkiye özeline döndürerek Türk sinemasının kendi dilini üretememesinin sebebini, Tanzimat Dönemi roman ve tiyatrosunun ardında bıraktığı geleneği bütünüyle reddetmiş olmasında $\operatorname{arar}^{6}$. Gerçekten de roman, tiyatro ve sinema Osmanlı'ya birbirine yakın sayılabilecek dönemlerde girmiştir. Yüzünü Batı'ya dönmeyi gelenekten kopmak olarak algılayan edebi görüşün sahne ve tasvir açısından canlı ve zengin Divan şiiri geleneğini reddi, sinema dilimizin oluşmamasında temel bir sebep olarak görülebilir. Şinasi'nin söyleyişiyle Tanzimat edebiyatının amacı “Asya'nın akl-ı pirayesi ile Avrupa'nın bikr-i fikrini izdivaç ettirmek"tir". Bu sözlerden de anlaşıldığı gibi romanın epistemolojisi yanlış anlaşılarak ahlakçı bir çizgide halkı eğitmek bağlamında ele alınmıştır. Bu kapsamda, roman ve tiyatroyu ortaya çıkaran sosyokültürel ve politik aşamaların yaşanmadığı bir ülkenin münevverler zümresince ortaya konmaya çalışılan edebiyat, sinemanın doğuşuna da denk gelen Tanzimat'la başlayan dönemde sakil ve sathi kalmıştır.

Divan şiirinin tasvir ve sahne kurma geleneğine ek olarak, sinemayla, "perde ve 1şık, müzik, çatışma, eleştiri ve gerçekçilik" gibi estetik, mekanik ve içeriksel ortaklıkların bulunduğu gölge oyununun da unutulması, imaj dilinin ve anlatıda yerliliğin yakalanamamasının bir başka sebebi olarak gösterilebilir ${ }^{8}$. Gemuhluoğlu'na göre ${ }^{9}$ Erksan "görsel bir modern mesnevi yazmak istemiştir ve anlaşılmak için bunu kahramanlarına söyletir: '-Bu zamanda kaldı mı böyle aşklar? -Tıpkı eski masallardaki gibi değil mi?"'10. Bu bağlamda Sevmek Zamanı'nın sinemanın asıl meselesi de olan ve Divan şiirince de dert edinilen imaj, suret ve muhayyile meselelerini hem biçim hem de anlatı açısından temel teması olarak belirlemesi onun önemini ortaya koymaktadır. İçerik ve görsellik bağlamından yaklaşıldığında, Erksan'ın Sevmek Zamanı filmi, bugün bile münferitliğini koruyabilen, döneminde ise son derece ayrıksı olan özgün bir eserdir.

Sevmek Zamanı, merkezindeki surete âşı olma konusuyla sadece tematik bağlamda değil, Erksan'ın bizzat sinema ve biçim üzerine düşündüğünü gösteren bir karaktere sahiptir. Yeşilçam'a alternatif geliştirmek isteyen ulusal sinema ha-

6 Gemuhluoğlu, a.g.e., s. 35-36.

7 Jale Parla, Babalar ve Oğullar: Tanzimat Romanının Epistemolojik Kökenleri, 12. bs., İstanbul, İletişim, 2016, s. 16.

8 Ali İhsan Kürekçi, "Beyaz Perdede Yaşayan İki Gölge: Karagöz ve Sinema”, Atatürk Üniversitesi Edebiyat Fakültesi Dergisi, say1 52, s. 169-184. http://dergipark.gov.tr/ataunisosbd/ issue/2809/37753, 2015, s. 169.

9 Gemuhluoğlu, a.g.e.

10 Metin Erksan (Yapımcı-Yönetmen), Sevmek Zamanı [DVD], Türkiye, Troya Film, 2007. 
reketinin kurucusu yönetmen Halit Refĭg' in, hem biçim hem de içerik bağlamında örnek model olarak bu filmi seçmesi bu cepheden okunmalıdır. Geleneğin, Gilles Deleuze'ün ${ }^{11}$ kavramsallaştırmasıyla zaman-imaja yaklaşır biçimde Andrei Tarkovsky sinemasına benzer bir görsellikle harman edildiği bu film, tasavvufi aşk temasının anlatının ana malzemesi olarak kullanılması açısından görsel, biçimsel ve tematik bağlamda bir yakın okumayı da hak etmektedir.

\section{“Küntü Kenzen Mahfiyyen Fe Ahbebtü En U'rafe Fe Halaktü'l-Halka Li Ya'rifünî"': Anlatı}

Tasavvufta iki aşk kapısı vardır: Aşk-1 mecazi (geçici aşk) ve aşk-1 hakıykıy/ hakiki (gerçek aşk) ${ }^{13}$. Aşk-1 mecazi bir kişiye duyulan sonsuz özlem ve isteği temsil eder; sufîlerce bir fikr-i sabit olarak onların deyimiyle siyahatle, yani ibret ve ibadete sığınılan bir yola girmekle kurtulunamayacak olan ancak mâşukla buluşmak ile çözümü mümkün bir dert olarak görülür. Yine de sevgili dışında dünyevi olan bütün maddi ve manevi bağları kırdığı, "yani insanı sevgiliye hasrettiği için", sufîler mecazi aşk1 da hoş karşılayarak onu "hakıykatin köprüsü" olarak görmüşlerdirr14.

Cezbe kelimesi, Arapça cezb kökünden türetilmiş, çekiş, çekmek anlamına gelen bir sözcüktür. Abdülbaki Gölpınarlı'ya göre Kur'an'da aşk kelimesi geçmediği, bunun yerine sevmek anlamına gelen hubb kelimesi seksen üç kez kullanıldığı için sufîlerce aşk sözcüğünün kullanılması sakıncalı bulunmuştur ${ }^{15}$. Bu açıdan Erksan'ın filmi adlandırırken aşk yerine sevmek kelimesini seçmesi manidardır. Sevmeye giden yol ise sufîlerce cezbe haline ulaşmaktan geçer. Yine Gölpınarlı'nın belirttiği gibi sufîlerce cezbe, mürşidini zikir, halvet (yalnızlığa çekilme, nefsiyle Hakk'a ulaşma) ve murakaba/murakabe (iç alemine dalarak Allah'ın kendisine nazarını tefekkür etme) yoluyla devamlı göz önüne getirerek ya da bir k1sım sufîlere göre sohbet yoluyla kişinin "gözünden ma-sive, yani Tanr1dan başka her şeyin silinmesi" biçiminde tezahür eden bir sûlük halidir ${ }^{16}$.

11 Gilles Deleuze, Cinema 2: The Time-Image, çev. H. Tomlinson R. Galeta, 6. bs., $2001 \mathrm{~b}$.

12 "Ben gizli bir hazine idim. Bilinmeye muhabbet ettim (sevdim) ve bilinmek için halkı yarattım" Hadis, İzahlı Divan Şiiri Antolojisi, aktaran Necmettin Halil Onan, İstanbul, MEB, 1991, s. 32-34.

13 Abdülbaki Gölpınarlı, Tasavvuf, ed. T. Türkmenoğlu, 4. bs., İstanbul, Türkiye, Milenyum, 2000, s.115.

14 Gölpınarl1, a.g.e., s. 116.

15 Abdullah Özcan, “Kur'an-1 Kerim'de Allah'in Sevdiği İnsan Tipleri”, Siirt Üniversitesi İlahiyat Fakültesi Dergisi, cilt 4, say1 2, 2017, s. 173-208, http://dergipark.gov.tr/siirtilahiyat/ issue/43339/527346a., s.175-176; Gölpınarlı, a.g.e., s. 264-265.

16 Gölpınarlı, a.g.e., s. 117. 
Tasavvuf, zahiri ve batıni olan arasında kalın bir çizgi çeker. Bir başka deyişiyle “Sufî, iç yönden Hakk'la sarhoş, dış yönden ise aleme ve onun nimetlerine karşı ayıktır" ${ }^{\text {. }}$. Bu zorunlu ayrımı göz önünde tutmak, dünya ve toplumla olan ilişkide davranış yönünden bilinçli bir farkındalığı da beraberinde getirir. Bu bağlamda Hakıyk'ın dizeleri de ayıklığa işaret etmektedir: "Ne hoştur ki cezbe ki ansızın gelir; yarısı da uyanık gönle erişir”; başka bir deyişle cezbenin sarhoşluğu hali ancak uyanık olan gönle gelmektedirr ${ }^{18}$.

Sarhoşluk, sufilikte Allah'1, filmdeyse sevmeyi bulmanın tezahürü ve meyvesidir. Sevmek Zamanı filminde Halil'in (Müşfik Kenter) Meral'e (Sema Özcan) söylediği "Sana dünyada hiçbir erkeğin bir kadına âşık olamayacağı kadar aş1ğım. Sana âşık kalmak istiyorum (...) Benim dünyama girmeye kalkma. Merhametsizce yıkarsın onu" sözleri sevmek meselesinde sarhoşluğun âşık olunan nesneden bağımsız olabileceği ve dış dünyanın geçiciliğini vurgulaması açısından tasavvuf görüşüyle ve onun aşk-1 mecazi düşüncesiyle örtüşür ${ }^{19}$. Tasavvufta Allah'ı bulmakla ilişkilendirilen sarhoşluk hali Halil'de bir surette yani Meral'in resminde karşılığını bulmuştur. Halil’in aşkını fark ettiği sahnelerde yağan yağmur, onun Boğaz kenarında bir meczup edasıyla yaptığı uzun yürüyüşler bu sarhoşluk halini görsel ve biçimsel anlamda betimlemektedir. Meczup kelimesinin $c e z b$ kökünden geldiği düşünülürse Halil'in durumu aynı zamanda ayıklığına da vurgu yapar, zira Halil, aşkına karşılık vermek istediğini söyleyen Meral'a cevab1 "Benimle resmin arasına girme. İstemiyorum seni! Ben senin yalnız resmine aşığım" olur ${ }^{20}$. Bu açıdan resim değişmezi temsil etmektedir. "Nihayet değişmezi bulmuştum. Resmin benim içime bakıyordu” repliği suretin Tanrı'yı olmasa bile Tanrısal olanı, hakikati vurguladığı nazarından değerlendirilebilir ${ }^{21}$.

Surete âşı olma teması Fars ve Osmanlı edebiyatının farklı metinlerinde değişik biçimlerde ele alınmıştır. Kimi metinlerde suret rüyada ya da sihirli aynada görülür, kimi metinlerde, suya yansımada; bazılarında suret kubbeye resmedilmiştir, bazı metinlerde ise suret, tıpkı Sevmek Zamanı filminde olduğu gibi duvardadır. Surete aşk, Osmanlı ve Fars şiirinin ortak simgelerinde varlığını bulan, sevgilinin bizzat bedensel varlı̆̆ı, resmi ya da Zatü'-suver (biçim kalesi)i ile temsil edilen bir temadır ${ }^{22}$. Geleneksel Osmanlı ve Fars şirinin en bilinen aşk hikaye-

\footnotetext{
17 William Chittick, Tasavvuf: Kısa Bir Giriş, çev. T. Koç, 1. bs., İstanbul, İz, 2003, s. 97.

18 aktaran Gölpınarlı, a.g.e., s. 118.

19 Erksan, a.g.e.

20 Erksan, a.g.e.

21 Erksan, a.g.e.

22 Gemuhluoğlu, a.g.e., s. 41.
} 
lerinde, Hüsrev ile Şirin'de, onun Ferhad ile Şirin'e dönüşmüş biçiminde, Vamık ve Azra'da, Hüsn ü Dil'de, Sihhat ve Maraz'da resme ya da aynada görülen surete âşık olma teması benzer biçimde işlenmiştir. Tüm metinlerde ortak olan ise aş1ğın sevgiliden önce suretini görmesi, büyülenme halini yaşayarak aşkta benliğini eritmesi ve akabinde sevgiliye ulaşmak için yollara düşmesidir ${ }^{23}$. Yani bu hikayelerde surete âşık olma teması, -vuslatın tezahür edip etmemesinden bağımsız olarak- bedensel bir kavuşmanın aracı, bunun için yapılan yolculuk da olay örgüsünün temel malzemesi olarak kullanılmıştır.

Sevmek Zamanı, bedensel kavuşmayı önemsizleştirerek Divan şiirinin aşk hikayeleri geleneğinden ayrılmış ve yönünü tasavvufa çevirmiştir. Halil için surete duyulan aşk nesnesinden bağımsız, kendi içinde yaşadığı bir hakikattir. Filmde Meral, evine işçi olarak giren Halil'in resmine karşı büyülenmiş bakışları karş1sında önce şaşırır. Bu onun daha önce rastlamadığı bir bağlanma biçimidir. Fakat ardından, kendi sınıfı içerisinde yalnızlık çeken kadın, Halil'in aşkına karşılık vermek ister. Halil ise sufî görüşle örtüşen biçimde "Resmin sen değilsin ki, resim benim dünyama ait bir şey" diyerek sevmenin batıni tarafına vurgu yapar ${ }^{24}$. Zahir olan alemdir, yani Meral'in ta kendisidir, fakat sevmek Halil için zahiri nesnesinden bağımsızlaşmıştır. Suret, aşığın kalbinde vücut bulmuştur ve bu bağlamda, sevmek, zahiri nesnesinden ziyade aşığa aittir. Tasavvufun önerdiği cezbe hali ölmeden önce ölmeyi de temsil eden bir varoluş biçimidir. Diri kalmak, aşkta ölmekle mümkündür. Mevlana'nın "Aşksız olma ki ölmeyesin/Aşkla öl ki diri kalasın" beyti sufi görüşün ontolojik bağlamda aşka ve ölüme bakışını ortaya $\operatorname{koyar}^{25}$. Halil'in aşk1 tasavvuf görüşüne uygun olarak, ontolojik onesnesine kavuştuğunda ölümle sonuçlanan bir aşkta ölmek halidir.

İbnü'l Arabi, Mevlâna, Ahmed Yesevi, Hacı Bayram Veli, Yunus Emre ve Niyazi Mısri’nin aşkın tasavvuftaki iki türünü yani Aşk-1 Mecazi ve Aşk-1 Hakikiyi birleştiren yolu sanatı küçümseyerek şiiri ahlaki bir yarara indirgeyen görüş tarafından akamete uğratılır. Bu durum, yeni-Platonculuğun "İbn Sina'c1 metafizikte" vücut bulmasının sonucudur. Bu idealist ve sanatı araçsallaştıran görüş, Tanzimat döneminde yeniden ortaya çıkmış ve günümüze kadar gelmiştir ${ }^{26}$. Yani Gemuhluoğlu'na göre Divan şirinde surete aşk, aşkta tenzih görüşüne uygun olarak küçümsenmiş; çıkıldıktan sonra itilecek bir köprü mertebesine indirgenmiştir.

23 Serpil Bağc1, "Mesnevinin Suretleri”, Mesnevi: Hikâyenin Şiiri, ed. H. Aynur, M. Çakır, H. Koncu, S. S. Kuru, \& A. E, İstanbul, Turkuaz, 2011.

24 Erksan, a.g.e.

25 Mevlânâ Celaleddin, Mevlana Celaleddin Rubailer, çev. A. Gölpınarlı, 1. bs., İstanbul, Türkiye, Inkilap, 2000, s.124.

Gemuhluoğlu, a.g.e., s. 37. 
Ancak sanatı araçsallaştırma tartışmasını bir kenara koyup tasavvufun sanatta kapladığı yere dönersek burada Gemuhluoğlu dünyevi aşk1 yani bir insan karşı hissedilen aşkı tıpkı Sevmek Zamanı filminin yaptığı gibi mecaza çevirmekle, başka bir deyişle gerçek olmadığı halde gerçeğe işaret eden bir kavramsallaştırmayla onu Allah'a ulaşmada bir vesile kılmanın aynı zamanda Aşk-1 Mecaziye terfi-i rütbe ettirmek anlamına geldiğini kaçırmaktadır.

Gemuhluoğlu benzer biçimde Erksan'ın aşk1 idealize ettiği sonucuna varır. Ona göre bu durum Erksan'da gelenekten kopuşun bir sonucudur. Gemuhluoğlu'na göre Sevmek Zamanı, bir aşk hikayesi olsa da mesnevilerdeki aşktan daha en başında ayrılır ${ }^{27}$. Yani Gemuhluoğlu için Halil'in aşk1 suretten manaya, zahirden batına yapılan bir yolculuk değil, tıpkı sanatın idealist yorumuna uygun olarak sadece bir "idea"dır ${ }^{28}$. Halil'in suretin aslını aramamasını tasavvufa uygun görmeyen bu bakış yanlış bir yaklaşımdır. Halil, tam da tasavvufun talep ettiği gibi dünyevi olandan vazgeçmiş, Tanrısal olanı imleyen surete ve onun kendi içinde uyandırdığı bütünleşme, maşukla bir olma cezbesine kapılmıştır. Surete âşık olma meselesinin tasavvuf nazarı dışında işlenmesi ancak Jokond ve SiYa-U (1929) ve Kürk Mantolu Madonna (1943) gibi Sevmek Zamanı'nin edebiyatımızdaki tematik öncülleri açısından bakıldığında doğru bir tespittir.

Surete âşık olma, sinemamızda ilk kez Sevmek Zamanı filmi ile işlense de bunun öncesinde Cumhuriyet Dönemi Edebiyatında Nazım Hikmet ve Sabahattin Ali gibi önemli isimlerin kullanageldiği bir tema olmuş; ancak tasavvuf nazarından bu temayı işlemek Erksan'a düşmüştür. Erken dönem eserlerinde Mevlâna etkisinin hissedildiği şiirler yazmış olan Nazım Hikmet'in Jokond ile Si-Ya-U (1929) şiirinde surete âşık olma temasını mesele etmesi şaşırtıcı değildir. Eserin en dikkat çekici yönü bir Uzak Doğulu olan Si-Ya-U'nun, Nazım Hikmet'in Jokond diye Türkçeleştirdiği, Batı'nın ve Rönesans'ın en önemli sembollerinden birine, Mona Lisa (La Giaconda)'ya âşık olmasıdır. Fakat bu şiirde Nazım Hikmet, Jokond'u canlandırır ve sevgilisi Si-Ya-U'nun peşinden Çin'deki devrimci harekete sokar. Şiirin "Bir İddia” başlığını taşıyan mukaddimesinde, Nazım Hikmet asıl Jokond tablosunun firar ettiğini ve yerine bir kopyasının konulduğunu iddia eder ${ }^{29}$. Yani değişmez olan kopyalanabilmiş ve bir bakıma değersiz olanı temsil etmiştir. Bu açıdan Nazım Hikmet'in görüşü, değişmezi hakikat sayan tasavvufa taban tabana zıttır. Nezahat Özcan'ın da ifade ettiği gibi Nazım Hikmet'e göre Jokond "tebessümüne mahkûm edilmiş bir tablo figürüdür" ve bu durum "onu bir

27 Gemuhluoğlu, a.g.e., s. 39.

28 Gemuhluoğlu, a.g.e., s. 39.

29 Nazım Hikmet, Bütün Şiirleri, 4. bs., İstanbul, Yap1 Kredi, 2008, s.78. 
metaya dönüştürmüştür”30. Sureti bir değişmezin ve hakikatin temsili yerine bir meta olarak ele almak, Nazım Hikmet' in bu temayı tasavvuf bağlamından açıkça koparıp diyalektik-materyalist görüşe göre yorumladığına işaret eder. Tasavvuf nazarını vurgulamasa da sureti kendisinden çok daha meşhur bir kimseyi seçip onu sonradan kişileştirmesi, Nazım Hikmet' in bakışını tasavvufunkine bir nebze yaklaştırır. Başka bir deyişle, tıpkı surete âşık olma temasındaki gibi Mona Lisa adıyla bilinen resim, La Giaconda isminde bir Rönesans aristokratının karısı olduğu tahmin edilen kişiden bağımsızlaşarak onun çok önüne geçmiştir. Ancak Nazım Hikmet'i tasavvuftan ayıran bir diğer nokta da değişmezi temsil eden resmi ete kemiğe bürüyerek ondan bu özelliğini almasıdır. Şairin sosyalist dünya görüşü, sureti Si-Ya-U'nun öldürülmesiyle cisimleştirerek bir özgürlük savaşçısına dönüştürmüştür. Jokond ve Si-Ya-U'nun Sevmek Zamanı ve tasavvufla kesiştiği nokta, her iki eserde de cisimleşen aşkın vuslata engel olmasıdır. Zira gerçek aşk bu dünyada değildir.

Sabahattin Ali'nin Kürk Mantolu Madonna (1943) eseri Sevmek Zamanı ile tematik bağlamda büyük benzerlikler taşısa da tıpkı Jokond ile Si-Ya-U'da olduğu gibi tasavvuf görüşünün ana hatlarıyla kesişmez. Ali'nin kimilerince novella olarak da nitelendirilen romanında, okumak için Almanya'da bulunan Raif, bir resim sergisinde gördüğü otoportreye âşık olur. Her gün gittiği resmin sergilendiği galeride portrenin sahibi olan Maria Puder ile tanışır. Ancak resmini "Bu portrede ne vardı? Bunu izah edemeyeceğimi biliyorum; yalnız o zamana kadar hiçbir kadında görmediğim garip, biraz vahşi, biraz mağrur ve çok kuvvetli bir ifade vardı" ${ }^{\prime 31}$, diye tasvir ettiği Puder'le tanıştıktan sonra Sevmek Zamanı'nın Halil'inden farklı olarak aşkını maşukuna tüm kudretiyle sunar. Aynı şekilde Raif ve Halil'in suretle karşılaşmalarında verdikleri tepkiler farklılıklar taşır. Halil, tüm kirli, bakımsız haline karşın ona sevgiyle bakan "değişmez"i bulmuştur ve Meral'le karşılaştığında onu bu meseleye dahil etmek istemez: "sana ait bir mesele değil bu. Resminle benim aramdaki bir durum seni ilgilendirmez. Ben senin resmine aş1ğım"32. Raif ise Puder'i canlı olarak gördükten sonra hemen ona aşkını sunmuştur: "Mademki o karşımdaydı ve benimle konuşuyordu, artık başka şeylerle meşgul olmak lüzumsuz ve manasızdı"33. Ancak Raif ve Halil vuslatı sabırla beklemek

30 Nezahat Özcan, "Nazım Hikmet'in Mona Lisa's1: Jokond ile Si-Ya-U”, Hacettepe Türkiyat Araştırmaları Dergisi, say1 21, 2014, s. 161-182, “Görüntüleme”: Nisan 21, 2019, https:// docplayer.biz.tr/20018813-Nazim-hikmet-in-mona-lisa-si-jokond-ile-si-ya-u-nezahat-ozcan. html, s. 166.

31 Sabahattin Ali, Kürk Mantolu Madonna, 15. bs., İstanbul, Yap1 Kredi, 2014, s. 213.

32 Erksan, a.g.e.

33 Ali, a.g.e., s. 76. 
konusunda birbirlerine benzerler. Hatta aşkına kavuşamadan ülkesine dönen Raif aradan yıllar geçtikten sonra bu üzün süre zarfında Puder'e kavuşamasa da aşkını hala korumaktadır. Sevmek Zamanı filmindeyse Meral'in de ona âşı olduğunu ilan etmesine rağmen Halil, aşkının öznesine uzunca bir süre direnir. Halil'in bu tutumu "sevdiği şeye ebediyen sahip olabilmek için çekilen bir korku"dur ${ }^{34}$. Raif Efendi'nin aşkına ömrü yettiğince sahip çıkması da Halil'le benzerlik gösterir. Ancak aşkı korkusuna galip gelen Halil sılasını vuslata dönüştürmeyi dener. Bu açıdan Halil ve Meral'in Başar (Süleyman Tekcan)' in tehdidine rağmen Raif Efendi'nin dervişane sabrını göstermedikleri bile söylenebilir. Ancak bu durum, film senaryosu ve romanın farklı kurgulara imkân veren yapısıyla da ilişkilendirilebilir. Bunlara ek olarak her iki eserde de mutlak aşkı arayan insanın, bir kişiye duyulan aşkla bunu tatmin edemeyeceği sonucu çıkarılabilmektedir. Halil değişmez olandan vazgeçip suretin sahibine döndüğünde âşık da maşuk da ölecektir. Raif Efendi ise kavuşamadığı nesnesini kendinin yaparak ömrü boyunca bu duygusunu koruyabilmiş, değişmez olana ulaşabilmiştir. Başka bir deyişle, Halil'in "resmin benim dünyama ait bir şey" ${ }^{35}$ demesi gibi Raif Efendi de Puder'i kendi yarattı̆̆ biçimiyle sevmeyi sürdürmüştür. Çünkü mecazî aşk, ancak aşkın nesnesini değişmez kılarsa devam edebilecektir. Sevmek Zamanı'nda suretin mutlak olanı hatta hakiki aşkı temsil ettiği görülür. Kürk Mantolu Madonna ise tüm benzerliklerine rağmen bir noktada kendisini sufî görüşten koyu çizgilerle ayırır. Tasavvufça bâtıni olanın hakikati temsil ettiğine dair inanç, Kürk Mantolu Madonna' da yerini materyalist bir bakış açısına bırakarak aşkın hayal, hakikatinse bu dünyada olduğu görüşüyle yer değiştirir: "Bu harikulade güzel rüya ne kadar çok devam ederse o kadar iyiydi. Onu kesmeye, hakikat pahasına da olsa uyanmaya hakkım yoktu"36. Son tahlilde, Sevmek Zamanı, kendisinden önce edebiyatımızda benzer temayı işleyen eserlere göre sufî görüşe bağlı kalmasıyla öne çıkmaktadır.

Sevmek Zamanı filmi, suretin hakikati temsil ettiği bir yaklaşımı konu eder. Tasavvufta Allah'ın ve onun sevgisinin içkinliği ile herhangi bir nesneye duyulan sevginin O'na duyulan sevgiyi temsil ettiği görüşü hakimdir ${ }^{37}$. Bu açıdan Sevmek Zamanı, dini olana açık göndermelerde bulunmasa da tasavvufi aşkı simgelediğini lisan-1 hal yani anlatı örgüsü ve görsel rejimi ile üstü kapalı beyan eder. Halil'in aşkının nesnesini reddedişi, surete aşkın hakikat olduğunun altını çizer. Filmin son bölümünde, Meral'in Başar'la evlenmekten vazgeçip Halil'in kayığ1na bindiği sahnede Halil, aşkını bir mankene gelinlik giydirerek sembolize etmiş-

34 Erksan, a.g.e.

35 Erksan, a.g.e.

36 Ali, a.g.e., s. 76.

37 Chittick, a.g.e., s. 221. 
tir. Bu gelinliğe rağmen ilk kez gördüğü suret yine kayıktadır. Fakat aşkın gerçek nesnesi Meral, bu mankeni kayıktan atarak onun yerine geçer. Tam da burada iki karakterin Başar tarafindan vurularak öldürülmeleri, hakiki aşkın bu dünyada var olmadığı, onun ancak temsillerinin mümkün olduğunu ve Aşk-1 Hakikinin nesnesine ulaşmanın insan-1 kâmil olmayan için ancak ahirete mahsus olduğunu belirten tasavvuf görüşüyle uyum halindedir. Zira tasavvufta ferdi kıyametin, yani ölümün vuslat kapısı olarak anılmasının bir sebebi de insan-1 kâmil olmayan için hakikate ulaşmanın tek biçimi olmasıdır.

\section{"Musavvir-i Ezel Edeli Nakşını Tasvîr/Yüzünü Hâke Sürer Çîn İçinde Sûretler" ${ }^{38}$ : Görsel Rejim}

Mesnevilerin nakkaşlarca resmedilmesinin en erken nüshalarına Nizami'nin hamsesinde rastlanır.14.Yüzyıl sonlarından itibaren resimlenmeye başlanan Nizami'nin eserinden sonra 15 . ve 16 . yüzyllarda bu gelenek yayılarak diğer öyküşiirlerin de görselliği okuyucularının hafızalarına nakşolunmaya başlanır ${ }^{39}$. Kitap resminin metinle birlikteliği giderek bir gelenek halini alır. Metin olmadan, tek yaprak olarak yapılabilir edebiyat yapıtlarından alınan sahneler, her zaman hafızadaki öyküyle, yani sözle anlamını kazanır ${ }^{40}$. Sevmek Zamanı görsel açıdan incelendiğinde, onun resimler üzerinden düşündüğü ve anlatısını kurmaya yöneldiği görülmektedir. Her planın birer fotoğraf karesi olarak kurgulanmış olması, filmin divan şiirine ve minyatüre vurgu yapan ana temasiyla uyum halindedir.

Fotoğrafın ortaya çıkışından beri tartışılan bir konu onun bu ana ait olmayan bir gerçekliği dondurması ve ölümsüzleştirmesidir. Roland Barthes fotoğraf makinesinin var oluş açısından asla yinelenemeyecek ve sonsuza kadar biricik ve aynı kalacak olanı, mekanik olarak yeniden ürettiğini vurgu$1 a r^{41}$. Minyatürler de özellikle yüzlerdeki ifadesizlik ile anın dondurulmasını ve kayıt altına alınmasını temsil eder. Buna ilaveten divan şiirindeki görsel tasvir zenginliği imgelemin sınırlarının açımlanmasına olanak vermektedir. $\mathrm{Bu}$ açıdan fotografik dille anlatı kurma biçimi Osmanlı şiirinin imgelemine uygun düşen bir biçimsel anlatı yoludur. Ayrıca şiirle kurulan hikayelerin pek çok örneğini içeren Osmanlı klasik şiiri, görsel tasvirleri de beraberinde düşün-

38 Şeyhi, (Allah nakşını tasvir ettiğinden beri, Çin içinde resimler yüzünü toprağa sürer) aktaran Sedat Kardaş, "Divan Şiirinde Resim ve Heykel”, Türkiyat Araştırmaları Enstitüsü Dergisi (TAED), say1 47, 2012. «Görüntüleme»: Nisan 21, 2014, http://www.turkiyatjournal.com/Makaleler/1733758972_Sedat KARDAŞ.pdf, s. 123.

39 Bağc1, a.g.e., s. 273.

40 Bağc1, a.g.e., s. 274.

41 Roland Barthes, Camera Lucida, çev. R. Akçakaya, 1. bs., İstanbul, 2000, s. 18. 
dügümüzde hareketli imaja dayanan sinemaya göz kırpan anlatı biçimlerinin kapısını aralamaktadır.

Sevmek Zamanı, fotoğrafi ele alışı bakımından enstantane fotoğraf biçimine yaklaşır. Tabiatı şiirsel bir üslupla ama durağan bir biçimde tasvirinin yanı sıra, donuk ifadeli yüzlere kadrajını çevirmesi, suretin değişmezliğine vurgu yapan ana tema ile örtüşür. Minyatür geleneğini vurgulayan bakış açısıyla görsel rejimini gerçekliğin enstantane çekimlerini almak isteyen, onu donduran bölünemez fotoğraf karelerinden kurar. Erksan'1n fotografik imgeleri, tasavvuf nazariyla da benzeşen Henri Bergsoncu süreyle de ilişkilendirilebilir ${ }^{42}$. Bu sürelerin bölünemez durağanlığında, bunların bilinç yoluyla seçilerek oluşturulan akışıyla hafiza, saf belleği oluşturur. Filmde yüz ifadeleri, tıpkı minyatürde olduğu gibi donuk, değişmez temsiller halinde verilerek hafizaya nakşolunur. Fotografik görsel rejim, "öykünün hem görünen yüzünü hem de uzantıları tasavvufun derinliklerine dek inen ve ash değil de suretle soyutlanan yanını" başka bir anlamda da filmin seyircideki hafızasını oluşturur ${ }^{43}$. Buna ek olarak suretin donuk derinliğine gizlenmiş esrar, filmin tasavvufi çatışmasını, yani hakikatin bu dünyada olmadığı ve ona bu dünyada aşk-1 mecazi ile ulaşılamayacağı gerçeğini seyircisine sezinletir.

Fotoğrafin geçmiş zamanı dondurması, onun ölümü hatırlatacak biçimde yaygınlaşmasına sebep olmuştur. Fotoğrafin ortaya çıkışında imajın işlenmesi uzun süreler aldığ için enstantane fotoğraf çekilememekteydi. Bu sebeple fotoğraf, ailelerin vefat eden üyelerini hatırlamak için kullandığı bir biçimsellikle yaygınlaşmıştır. Bu durum fotoğrafin dünya nimetlerine tamahkarlığa karşı kanaatkarlığı tavsiye eden memento mori (ölümü hatırla!) anlayışıyla doğduğu düşüncesini de beraberinde getirir ${ }^{44}$. Başka bir deyişle fotoğraf, aynı zamanda kendinin ve diğerinin faniliğini hatırlamaktır. Bu bağlamda filmde fotoğraf ölümlü olanın ölümsüzleştirmesi biçiminde ele alımır. Halil'in Meral yerine onun fotoğrafını seçmesi, değişmez olana yani hakiki aşka yöneldiğinin işareti olarak yorumlanmalıdır.

Fotoğrafın memento mori anlayışıly yaygınlaşması nefse eğitimine vurgu yapmasıyla da hem İslam'ın batıni görüşüne uygun düşer. Tasavvuf görüşünde dünya nimetlerinden el etek çekmek, ihtiyacın asgarisiyle hayatı idame etmek nefis terbiyesinin en temel yollarındandır. Bu yolda tul-i emel olarak tanımla-

42 Henri Bergson, The Creative Mind, çev. M. L. Andison, New York, The Philosophical Library, 1946.

43 Tunç Yıldırım, "Metin Erksan'ın Sevmek Zamanı Filminin Eleştirel Alımlaması”, Global Media Journal, TR Edition, cilt 5, say1 9, 2014, s. 352-371.”Görüntüleme”: Nisan 24, 2018, http:// globalmediajournaltr.yeditepe.edu.tr/sites/default/files/Tunç YILDIRIM .pdf, s. 71.

44 Susan Sontag, On Photography, 1. bs., New York, Rosetta, 2005. 
nan mal ve dünya tutkusu Kur'an'da Nahl suresindeki bir ayetten yola çıkılarak olumsuzlanır ${ }^{45}$. Halil'in Meral'in isteğine rağmen onu geri çevirmesi, filmde sunulan sufi görüşün nefse hakimiyet anlayışının altını çizer.

Sevmek Zamanı, görsel rejimini, suya akislerden, pencereden bakışlara, Halil'in resmi seyretmesinden, Meral'i dışarıdan izlemeye hep nazar ve yansımalar ile ilişkilendirir. Burada tasavvuf düşüncesinde maşuğun yansıttıklarına ve ayna üzerinden yaratılan derin ve zengin metaforik anlatıma bakmak gerekir. "Mümin müminin aynasıdır" mealine gelen hadiste olduğu gibi ayna anlamına gelen "mir'at" kelimesinin Peygamber sözlerinde mecazi anlamda çokça geçmesi sufi görüş tarafından bu sözcüğün ilgi görmesine sebep olmuştur ${ }^{46}$. Örneğin İbnü’1 Arabi, Fususu'l Hikem'inde ayna metaforunu, "Tanr1-alem, insan, insan-1 kâmil ve kalp kavramlarını açıklamak için kullanmıştır”" . Sevmek Zamanı'nda ilahi bir aşktan bahsedilemeyecek olsa da de buna kapı olan Aşk-1 Mecazi açık bir biçimde işlenmektedir. Tasavvufta aşkın hükmettiği kalp Allah'ın nazarının tecelli ettiği ayna olarak görülmüş, sufinin de kalbi yoluyla sevgilinin yani Hakk'ın yansımasını temaşa ettiği bir ayna olarak kullanılmıştır. Filmde, bu nazar Meral'in bakışına çevrilmiş, Halil'in uzun uzun seyrettiği nazar aslında Meral'in kendi kalbine yüzünü dönen bir ayna olmuştur. Aynı zamanda ayna, sufinin kalbini ve Allah'ın cemalini seyretmek için yarattığı alemi ve insanları da temsil eder. Aşk-1 Mecazi kavramını anlatı örgüsünün merkezine oturtan Sevmek Zamanı'nda maşuk Hakk ile değil bir insan suretiyle temsil edildiği için tıpkı Allah'ın sufide kendi cemalini seyretmesinden zevk alması gibi, Meral de kendi suretine bakılmasından haz duyar. Halil'i kendi resmini seyrederken gören Meral, Halil'e fark ettirmeden suretine odaklanan nazarı izler. Suret, burada bir ayna görevi görerek Meral'de aslında kendisinin seyredildiği duygusunu uyandırır. Bu durum, Erksan'ın görüntü rejimiyle desteklenir; film Meral'i fark ettirmeden pencere kenarlarından, kapı boşluklarından izleyen bir göz ile takip ediyormuş hissi yaratan bir kamerayla seyirciye aktarılır. Ayna metaforunun altını çizmesi bakımından suya akislerin defaten gösterilmesi de benzer bir etki yaratır. Fakat Halil'in baktığı Meral değil onun sureti ve o suretin temsil ettiği kendi kalbidir. Cezbe halindeyken Meral'in odaya girdiğini bile fark etmeyen Halil, maşukuyla vahdet haline girmeye doğ-

45 Reşat Öngören, “Tasavvuf”, Türk Diyanet Vakfi İslam Ansiklopedisi (T.Y.), „Görüntüleme“: Nisan 20, 2014, http://www.islamansiklopedisi.info/dia/pdf/c40/c400057.pdf, s. 290.

46 Süleyman Uludă̆, “Ayna”, İslam Ansiklopedisi İçinde, (T.Y.). „Görüntüleme“: Nisan 22, 2018, http://www.islamansiklopedisi.info/dia/maddesnc.php?MaddeAdi=ayna, s. 261.

47 Ahmet Ögke, „İbnü>l Arabi‘nin Fususu'l-Hikem‘inde Ayna Metaforu“, İlmi Ve Akademik Araştırmalar Dergisi (İbnü>l Arabi Özel Sayısı), sayı 23, 2009, s.75-89, „Görüntüleme“: Nisan 21, 2018, http://www.tasavvufdergisi.net/Makaleler/1747162164_23.6.pdf, s.75. 
ru yönelmiştir. Ancak vahdet, bu dünyada ancak insan-1 kâmil için mümkündür. Tasavvuf bu sebeple ayna metaforunu ikiye ayırmış; vahdeti temsil etmek için ancak kâmil insanların ulaşabileceği mir'at'ü'l-Hak kavramını kullanmış; daha alçak bir seviyede, halkı ve kesreti temsilen mirat'ü'l-halk kavramına baş vurmuştur. Halil ise aşk-1 mecazi safhasında kalmış bir seven olarak "tecelli edenle tecelli edilenin birbiriyle karışıp birleştiği iltibas makamı"na yani vahdete ancak ölüm yoluyla erebilecektir ${ }^{48}$. Susan Sontag'ın ifade ettiği gibi "Ressam inşa ederken, fotoğrafçı açığa vurur" ${ }^{\prime \prime}$, ancak açığa vurduğu yokluğun işaretidir. Bu açıdan bakıldığında Halil'in bu dünyadaki yokluğunun, surette kıldığı yaşamının üzerine bina edilen anlatının görsel dille uyum halinde olduğu anlaşılır.

Meral'in çekim açılarında özellikle Halil'le karşı karşıya bulunduğu sahnelerde ondan yüksek konumlandırılması Meral'in oluşturduğu arzu nesnesinin üstünlügünün altını çizmek olarak yorumlanabilir. Bu açıdan görsel rejimin tema bağlamından zaman zaman koparak bir kafa karışıklığı sergilediğini iddia etmek de mümkündür. Yani Halil'in batıni biçimde yaşadığ aşk, onu surette nesneleştirdiği ve kendine ait kıldığı yönle kendini inşa etmiştir. Ancak bu kafa karışıklığı Halil'in olay örgüsünde yaşadığ 1 ana çatışmaya uygundur. Yani Halil, Derviş Mustafa'nın (Fadil Garan) da telkinleriyle filmin bir bölümünde aşkını, suret yerine suretin sahibiyle yaşamak istemiştir. Ancak Meral'in Halil'e karşı perdede yüceltilmiş konumu sadece bu bölümünde görülmez, filmin geneline yayılmıştır. $\mathrm{Bu}$ açıdan bakıldığında durum, Meral'in Tanrısal bir tasavvurda çizildiğini ima etmektedir. Yani sadece sureti değil, suretin sahibi olarak âşık olunan nesne, -sufi görüşe göre her insanda içkin olan ancak ayna gibi parlatılmadığı müddetçe isli halde bulunaniyice sırlanmış bir aynayı, yüceltilmiş Tanrısal bir özü temsil etmektedir. Filme bu yönden bakıldığında görsel rejimde tutarlılı̆̆ın korunduğu anlaşılabilir.

\section{"Harabat Ehline Düzâh Azabın Anma Ey Zâhid/ Ki Bunlar İbn-i Vakt Olmuş Gam-ı Ferdayı Bilmezler"50: Kurgusal Zaman}

Deleuze'e göre sinemada hareket-imaj ve zaman-imaj olmak üzere iki tür görsel rejim biçimi vardır. Kurgunun ve kesmelerin şekillendirdiği bu düşünceye göre hareket, imajın içinde zaten saklıdır, yani sinema tek tek fotoğraflar yoluyla

48 Uludağ, a.g.e., s. 261.

49 Sontag, a.g.e., s. 71-72.

50 Hayali, (Sufi, bulunduğu ân içinde yapması gerekeni, kendinden isteneni yaptığı için ibn-i vakttır, yani zamanın oğludur) aktaran Hümeyra Yuva, "Türk Şiirinde Zaman Temininin Değişimi”, Turkish Studies International Periodical for the Languages, Literature and History of Turkish or Turkic, 4, 2009, s. 1661, „Görüntüleme“: Nisan 21, 2018, from http://turkoloji. cu.edu.tr/YENI TURK EDEBIYATI/humeyra_yuva_turk_siiri_zaman_temi.pdf 
hareketin oluşturulduğu bir göz yanılsaması olarak görülmemelidir. Hareket-imaj, sinemaya ait hareketlilik yoluyla sağlanan bir zaman algisı üreterek, her kesmenin birbiriyle ilişkide olduğu, zamanın kurguya içkin ve ona göre mekanik bir biçimde tasarlandığ 1 bir montaj rejimi kurar. Zaman-imaj ise görüntünün zamanı kendine ait kıldığı, hareketin ötesine geçen ve her kesmenin yekpare bir bağımsız bütünü temsil ettiği kurgu yöntemidir ${ }^{51}$. Gemuhluoğlu, mesnevideki vezni, sinemadaki kurguya benzetir, çünkü her ikisi de ritmi tanzim ederek anlatının zamanla ilişkisini nasıl kurduğunu açık eder ${ }^{52}$. Bu açıdan Gemuhluoğlu'nun görüşü, Bergsoncu zaman algisıyla örtüşen biçimde tasavvufun, geçmiş, bugün ve gelecekle bağlantı kurarak, tıpkı Ahmet Hamdi Tanpınar'ın “Yekpare, geniş bir anın/ Parçalanmaz akışında" diye tasvir ettiği gibi tek parça bir zaman algısını temsil ettiğini imler ${ }^{53}$. Bu zaman, sufinin zamanıdır, çünkü sufi, ibnü'l vakt (vaktin çocuğu) olarak pişmanlık yani geçmiş ve tul-i emel yani gelecekten münezzeh, tecelliyle dolu "her dem yeni bir şende" varlık bulmaktadır ${ }^{54}$. Bu bağlamda aktarılan zamanda birlik meselesi, Bergsoncu düşünceden esinlenilerek oluşturulmuş Deleuzcü imge görüşünde zaman-imajda tezahür ederek her kesmenin zamanı kendi içinde mühürleyerek bağımsızlaştıran kurgusal yaklaşımıyla mümkün olur.

Gemuhluoğlu, Sevmek Zamanı filmini görsel rejimi açısından içerik bağlamından kopuk bularak iç ve dış bakışlar üzerinden işleyen kurgunun "birbirine geçemeyen, bağlanamayan" bir gerilim ortaya çıkardığını savlar ${ }^{55}$. Her ne kadar, zaman-imajı Deleuzcü yaklaşımla Türk sinemasında uygulayabilen yönetmenlerin Nuri Bilge Ceylan ve Semih Kaplanoğlu gibi son dönem yönetmenlerin olduğunu düşünsek de Erksan'ın imaj üzerine kafa yorulmayan bir dönemde giriştiği denemesi yabana atılmayacak bir kurgusal rejim ortaya koymaktadır. Zamanı görüntüye aşılayan planlar, filmin her yanına sirayet etmemiş de olsa o güne dek görülmemiş bir beceriyle kurgulanmıştır. Tıpk1 sufi görüşün, zamanı bir bütün olarak ele alması gibi, Erksan da çoğunlukla planlarını genelde birbirinden bağımsız birer bütün ve tek gövde olarak inşa edebilmiştir. Zaman, bu filmde hareket-imajdaki gibi kurguya göre şekillendirilmiş olarak değil, kendi gerçekliğinin akış hızına ve planın önceliğine uygun bir biçimde verilir.

Aktörün gözüymüş yanılsamasıyla yakalanan çekim yöntemi (point-of-view/ PoV), filmin tasavvufi bakışına uygun bir biçimde hem halkın kesretini hem de

51 Gilles Deleuze, Cinema 1: The Movement-Image, çev. H. Tomlinson \& B. Habberjam, 6. bs., Minneapolis, University of Minnesota, 2001a, s. 11.

52 Gemuhluoğlu, a.g.e., s. 44.

53 Ahmet Hamdi Tanpınar, Bütün Şiirleri, 21. bs., İstanbul, Dergah, 2011, s. 19.

54 Gemuhluoğlu, a.g.e., s. 44.

55 Gemuhluoğlu, a.g.e., s. 45. 
doğadaki vahdeti yansıtmaktadır. Meral'in resmine bakışta aktörün gözündenmişçesine alınan görüntüler, surete aşkın temellendirdiği, aşkla ulaşılan birliği aktarması açısından hayatidir. Erksan'ın dış mekândan içe yönelen ve bazen aşk nesnesine neredeyse dikizci bir biçimde yaklaştığı çekimler, tasavvuftaki ayna metaforunun Allah'ın nazarının her an kalpte olduğunu hatırlatan görüşüyle ve simanın kalpteki Allah nazarını yansıtan bir temaşa unsuru olarak tasvir edilmesine de uygun düşmektedir.

\section{"Nâ-Ehl Olur Muârız-ı Ehl / Her Ahmed'e Bulunur Ebû Cehl"\$6: Çatışma Örgüsü}

Sinemacılar Dönemine toplumsal-gerçekçi biçim ve anlatılar egemen olmuştur. Hatta kimilerine göre bu akım Erksan'ın “Türkiye'de ekinlerin bu kadar cılız olamayacağı” gerekçesiyle sansüre uğramasıyla maruf, 1952'de yönettiği filmi Karanlık Dünya filmi ile başlar ${ }^{57}$. Erksan, Sevmek Zamanı filmine kadar toplumcu-gerçekçi eserler vermeye devam eder. Sevmek Zamanı ise yönetmenin filmografisinde ayrıksılığını bütçe, gişe hedefi gibi meselelerde de gösteren yapımcılığını bizzat Erksan'ın üstlendiği bağımsız bir yapım olur. Filmin maliyeti 60 bin TL (o dönemde çekilen bir uzun metrajlı filmin maliyeti ortalama 250 bin TL'dir), oyuncuları Yeşilçam'da bilinmeyen tiyatro kökenli isimsiz aktörlerdir ${ }^{58}$. Bu açıdan bakıldığında Erksan'ın bağımsız ve döneminin sosyoekonomik taleplerinin dışında bir yapıt ortaya koyma iradesi gösterdiği açıktır. Ancak gösterdiği iradenin etkisi, daha önce işlediği tematik meselelerini de filmin içerisine serpiştirmeye çalışmasıyla zayıflamıştır. Erksan'ın röportajlarında da belirttiği üzere filmin "toplum sınıfları arasındaki zengin-fakir iki insanın aşkını" 59 aktarma çabas1 geçmiş toplumcu-gerçekçi geleneğine göndermeler yapmas1 onun içerik ve biçimsel bağlamda bir bütünlük arz edebilecek eserinde bütünlüğü dağıtan ve yer yer parçalayan bir unsur olmuştur. Yani filmin merkezi çatışması olan mecazi aşk ve bedensel aşk eksenine eklemlemeye çalıştığı ve Doğu-Batı meselesiyle ilişkilendirmeye çalıştı̆̆ zengin-fakir ikiliği filmin öykülemesinde bir kafa karışıklığına işaret etmektedir. Biçimde üretilen dilin zenginliği tasavvufla örtüşürken yine aşk-1 mecazi ve bedensel aşk çerçevesinde zaten yakalanmış olan çatışmaya,

56 İbn Kemal'den aktaran Muarız, (T.Y.), Kubbealtı Lugatı, "Görüntüleme”: Nisan 24, 2018, http://lugatim.com/s/MUÂRIZ

57 Mesut Kara, Toplumsal Gerçekçi Sinema Metin Erksan 'la Başlar (2012, 07 Ağustos), para.1, "Görüntüleme": 24 Nisan, 2018, https://sadibey.com/2012/07/31/toplumsal-gercekci-sinema-metin-erksanla-baslar/\#.Wt-0JMiFNPY.

58 Yildırım, a.g.e., s. 357.

59 Yildırım, a.g.e., 355. 
rakip zengin erkek ve baba figürleri dahil edilerek geleneksel-modern ikiliğinde temsil edilen ana tearuzun etkisi, dağıtılarak aşındırmaya uğratılmıştır.

Georgous Sadoul'a göre Sevmek Zamanı, "son derece büyük bir sınıf çatışmasını gösteren film"dir ${ }^{60}$. Çatışmanın bu kadar büyük ölçüde örüldüğü iddia edilemeyecek olsa da doğru olan, sınıf çatışması ile birlikte ve ondan bağımsız olarak Doğu-Batı meselesinin de filmin çatışma örgüsüne dahil edildiğidir. Karakter inşası üzerinden denenen bu örgü büyük anlatılara meylederek filmin biçim-içerik uyumuna zarar verir. Öncelikli olarak Derviş Mustafa'nın isminden beklendiği gibi anlatısal uyumu tamamlayabilmek için sufi geleneğe uygun çizilmesi beklenirken Halil'i aşkının temsil ettiğine değil de Meral'in şahsına doğru yönlendirmesi tasavvufçu ana tema ile çelişmektedir.

Doğu-Batı ikiliği, Derviş Mustafa, Halil ve onların karşısında konumlandırılan Başar ve Meral'in babası (Adnan Uygur) fakir (Doğu)-zengin (Batı) ikiliğiyle iç içe aktarılmak istenmiştir. Bu ikilik özellikle üretim biçimlerinin temsili açısından bakıldığında yetkin bir temsil olarak görünmektedir. Yönetmen, Doğulu ve eskiyi temsil eden üretim biçimine sadık zanaatkar Halil'in karşısında Sanayi Devrimi sonrasını temsil eden fabrikatörleri konumlar. Ancak sinemamızda o güne kadar da fazlaca işlenmiş zengin kız-fakir oğlan diyalektiğine göre verilmeye çalışılan Doğu-Batı meselesi, bu filmde iki ayrı suda yüzen bağımsız fenomenler gibi paraleller halinde akıp gitmektedir. Sosyolojik bağlamından koparılarak bir aşk hikayesinin kavuşamama unsuruna indirgenmiş bu durum, ne Doğu'nun Batı karşısında yoksulluğunun sebebini imleyebilen bir karakter temsili, ne de bunun bireylere iz düşümünün nedenlerini sorgulayabilen bir bütün teşkil edebilmektedir. Zira surete aşk temasının işlendiği filmde bu türden meseleleri ele almaya çalışmak bir kafa karışıklığının filmin yer yer anlatısına ancak çokça da karakter inşasına da hâkim olduğunu gösterir. Yani Erksan, biçimle anlatıyı buluşturduğu ve geleneksel-modern iskeletine inşa ettiği surete aşk gövdesinin yanına hepsi tek başına devasa gövdeler olarak işlenmeyi bekleyen sınıf çatışmas1, (yoksul) Doğu- (zengin) Batı meselesi gibi (yan) konular serpiştirerek filmin ana ekseninden kaymasına sebep olmuş, anlatı ve karakter inşasını bozduğu gibi, biçimsel kaymalara da olanak tanımıştır. Film boyunca şiirsel bir görsel dil tutturabilmiş Erksan neredeyse gerçeküstücü bir anlatıma olanak verebilirken, bu görsel bütünlük çatışmayı genişletmek istediği öykülemesi nedeniyle biçim-içerik uyumunu yer yer akamete uğratmıştır.

Aynı durum filmin müzik ile kurduğu ilişkide de de geçerlidir. Filmde Derviş Mustafa'nın bir udi olarak tasvir edilmesi yönetmenin klasiğe ilişkin kaybedil- 
mekte olanları hatırlatma çabasının altını çizer. Özellikle Halil'in suret karşısında büyülendiği sahnelerde fonda udun çalması bu arzunun tezahürüdür. Klasik musikinin yanında özellikle ara geçişlerde kullanılan piyano tınılarıyla biçimsel açıdan bir sentez yakalanmaya çalışılır. Ancak Doğu ve Batı müziği, filmde, tıpkı Sergei Eisenstein'ın D.W. Griffith'in “burjuva montajı” olarak andığı kurgusundaki eleştirisine benzer biçimde ne diyalektik oluşturabilen ne de birbirine karışma hali gösterebilen bir yan yana durma biçiminde kendini belli eder ${ }^{61}$. Yani Erksan, ancak birbirine değmeyen gerçek bir gerilimin ya da iç içe geçmişliğin görülmediği bir ses kurgusu/tasarımı oluşturabilirmiştir. İki unsur, iddialı olabilecek bir yorumla Türk modernleşmesinin de bir yansıması olarak görülebilecek biçimde ancak sonsuzda buluşabilecek ayrışmış ya da hiçbir araya gelememiş iki dünyayı temsil edebilmektedir.

\section{“Âşık Öldü Deyu Sala Verirler/ Ölen Hayvandürür Âşıılar Ölmez”"22: Sonuç}

Metin Erksan'ın Sevmek Zamanı filmi, tasavvuf geleneğiyle kurduğu bağ ve ona uygun yenilikçi bir biçimsel dil kurma çabasıyla modernist bir öze sahiptir. Yönetmenin anlatı bağlamında sufilerin aşk-ı mecazi anlayışına yakın durarak aktardığ1 surete âşık olma teması, biçimsel ve kurgusal dille desteklenerek bütüncül bir anlayışla aktarılmaya çalışılmıştır.

Türk sinemasının henüz görsel rejimini oluşturamadığı açıktır. Bu durumu Ulus Baker, İran sinemasıyla bir karşılaştırma yaparak sinemamızın klasik kültürümüzden yani Divan şiirinden ve onun resmedici öyküleme biçiminden Tanzimat Dönemi'yle beraber kopuşuna bağlar ${ }^{63}$. Bu bağlamda, Sevmek Zamanı filminin yenilikçi bir eser olarak özellikle görsel bağlamda anlatısıyla örtüşmeyen ve yer yer özgünlükten kopan özelliklere sahip olması şaşırtıcı gelmemelidir. Gemuhluoğlu'na göre ise bu durumun müsebbibi Erksan'ın da geleneğiyle bağlantısını Tanzimat Dönemiyle beraber koparmış bir kültürün ürünü olmasıdır ${ }^{64}$. Yine de sinema imajlarla düşünmek ise bunu ülkemizde ilk kez gerçekleştiren yönetmenin Erksan olduğunun altı önemle çizilmelidir. Sinema gerçekliği bir muhayyile düzeyinde göstergeler rejiminde aktaran, görüntülerin sayeleriyle dolaylı yoldan düşünen bir sanat ise, bu sanatın ülkemizde tahayyül gücünün görsel bağlamda-

61 Baker, a.g.e., s. 140.

62 Mehmed Demirci, “Ölümdeki Hayat: Tasavvuf Düşüncesinde Ölüm”, Tasavvuf: İlmi Ve Akademik Araştırmalar Dergisi, (T.Y), s.13, "Görüntüleme": Nisan 21, 2018, http://www.tasavvufdergisi.net/DergiArama.aspx?Turu=True $\&$ Kelime $=$ Mehmet Demirci

63 Baker, a.g.e., s. 109.

64 Gemuhluoğlu, a.g.e. 
ki kısırlığını anlamak için divan edebiyatının sembolizmini ve resmetme kabiliyetini unutan ve bu öykülemeci yönü de son derece gelişkin şiir biçimini bir mazmunlar dizgesine indirgeyen anlayışın sorgulanması da gerekmektedir. $\mathrm{Bu}$ açıdan sinemamız Deleuze'ün tıpkı şiirin sağladığı duyumlar gibi sözel-öncesi (pre-verbal) ve dil-öncesi (prelinguistik) bir duyum biçiminde anlaş1labilir olmasını beklediği bir imgesel ve göstergebilimsel kompozisyon olarak gelişmemiş, Erksan'ın bu ilk denemesini beklemek zorunda kalmıştır ${ }^{65}$. Klasik şiirinin muhayyile ve resmetme gücünden kopmuş Türkiye sinemasına nazaran kendi şiiriyle bağını koparmamış İran sineması, tüm dünyada gücünü hissettirebilmiş; bu sinemanın görsel şiirinden etkilenen Semih Kaplanoğlu, Nuri Bilge Ceylan ve Derviş Zaim gibi sinemacılarla filmlerimiz, gerçek anlamda imajlar yoluyla düşünmeye ve soyutlamalara başlayabilmiştir.

Film, diyalektik kişileştirmelerin fazlaca anlam yüklenerek tasarlanması ve ses kurgusunda görülebilen bazı problemleri de içinde barındırmaktadır. Ancak yine de Sevmek Zamanı mekânsal görselliğin ana temaya uygun kullanılmasıyla, dikizci ve aktörün bakış açısını yansıtan kamera hareketleriyle, sudan, yağmurdan ve akislerden faydalanan görsel seçimleriyle, aşkın yaşanışındaki içselliği yansıtan aktörüne yabancılaşabilmiş çekim açılarıyla, planlarını hem hissedilen zamana hem de nesnel zamana göre ayrı ayrı biçimlendiren ve kesmelerini çoğunlukla planı zamanı kendine ait kılmış bağımsız bir unsur olarak verebilen yetkinlikte ayarlayan kurgusuyla, genel olarak anlatı ve öykülemesini biçimle bir bütün haline getirebilmiştir. Yani filmde içerik, biçim ve üslubun ahenkli olduğu kolaylıkla iddia edilebilir. İşlediği temanın geleneği temsil eden yenilikçiliği, Tanzimat Edebiyatıyla anlatı türlerinde klasikten kopmuş bir kültürde övgüyü tek başına hak ederken, ülkemizde daha önce örneğine rastlanmamış bir görsel dil oluşturma girişimi ve zaman-imaja yaklaşan kurgusuyla Sevmek Zamanı, döneminden özgün, modernist yaklaşımıyla sinemamızda halen ayrıntısıyla keşfedilmeyi bekleyen münferit bir ada gibi beklemektedir. 


\section{Kaynakça}

Abdülbaki, Muhammed Fuad, Kur'an Kelimelerinin Anahtart: Kur'an-ı Kerim'de Geçen Kelimelerin Manaları ve Geçtiği Yerler (El Mu'cemu Elfâzi'l-Kur'an-ı Kerim, çev. M. Çanga, İstanbul, Timaş, 1986.

Ali, Sabahattin. Kürk Mantolu Madonna, 15. bs., İstanbul, Yap1 Kredi, 2004.

Bağc1, Serpil, "Mesnevinin Suretleri”, Mesnevi: Hikâyenin Şiiri, ed. H. Aynur, M. Çakır, H. Koncu, S. S. Kuru, \& A. E, İstanbul, Turkuaz, 2011.

Baker, Ulus, Beyin Ekran, ed. E. Berensel, 4. bs., İstanbul, Birikim, 2017.

Barthes, Roland, Camera Lucida, çev. R. Akçakaya, 1. bs., İstanbul, Altıkırkbeş, 2000 .

Bergson, Henri, The Creative Mind, çev. M. L. Andison, New York, The Philosophical Library, 1946.

Celaleddin, Mevlânâ, Mevlana Celaleddin Rubailer, çev. A. Gölpınarlı, 1. bs., İstanbul, Inkilap, 2010.

Chittick, William, Tasavvuf: Kısa Bir Giriş, çev. T. Koç, 1. bs., İstanbul, İz, 2003.

Deleuze, Gilles, Cinema 1: The Movement-Image, çev. H. Tomlinson \& B. Habberjam, 6. bs., Minneapolis, University of Minnesota, $2001 \mathrm{a}$.

, Cinema 2: The Time-Image, çev. H. Tomlinson \& R. Galeta, 6. bs., Minneapolis, University of Minnesota, 2001b.

Demirci, Mehmet, "Ölümdeki Hayat: Tasavvuf Düşüncesinde Ölüm”, Tasavvuf: Illmi ve Akademik Araştırmalar Dergisi, cilt 9, say1 6, (T.Y.), "Görüntüleme": 21 Nisan, 2018, http://www.tasavvufdergisi.net/DergiArama.aspx?Turu=True\&Kelime $=$ Mehmet Demirci.

Erksan, Metin, (Yapımcı-Yönetmen), Sevmek Zamanı [DVD], Türkiye, Troya Film, 2007.

Gemuhluoğlu, Zeynep, “Mesnevi'den Sinemaya Aşk, Suret ve Zaman”, Hayal Perdesi, (32), cilt 34, say1 45, 2013, "Görüntüleme": 21 Nisan, 2018, http:// www.hayalperdesi.net/haber/yorum/2667-1-mesneviden-sinemaya-ask-suretve-zaman.aspx

Gölpınarlı, Abdülbaki, Tasavvuf, ed. T. Türkmenoğlu, 4. bs., İstanbul, Milenyum, 2000.

Hikmet, Nazım, Bütün Şiirleri, 4. bs., İstanbul, Yapı Kredi, 2008. 
Kara, Mesut, Toplumsal Gerçekçi Sinema Metin Erksan'la Başlar, (2012, 7 Ağustos),"Görüntüleme": 24 Nisan, 2018, https://sadibey.com/2012/07/31/toplumsal-gercekci-sinema-metin-erksanla-baslar/\#.Wt-0JMiFNPY

Kardaş, Sedat, "Divan Şiirinde Resim ve Heykel", Türkiyat Araştırmaları Enstitüsü Dergisi (TAED), say1 47, 2012. "Görüntüleme": 21 Nisan, 2014, http:// www.turkiyatjournal.com/Makaleler/ 1733758972_SedatKARDAŞ.pdf

Kürekçi, Ali İhsan, "Beyaz Perdede Yaşayan İki Gölge: Karagöz ve Sinema", Atatürk Üniversitesi Edebiyat Fakültesi Dergisi, say1 52, 2015, http://dergipark. gov.tr/ataunisosbd/issue/2809/37753

Muarı, Kubbealtı Lugatı, (T.Y.), "Görüntüleme": 24 Nisan, 2018, http://lugatim.com/s/MUÂRIZ

Ögke, Ahmet, “İbnü〉1 Arabi’nin Fususu'l-Hikem'inde Ayna Metaforu”, İlmi ve Akademik Araştırmalar Dergisi (İbnü>l Arabi Özel Sayısı), sayı 23, 2009, "Görüntüleme": 21 Nisan, 2018, http://www.tasavvuf dergisi.net/ Makaleler/1747162164_23.6.pdf

Öngören, Reşat, “Tasavvuf”, Türk Diyanet Vakfi İslam Ansiklopedisi, (T.Y.), "Görüntüleme": 20 Nisan, 2014, http://www.islamansiklopedisi.info/dia/pdf/ c40/c400057.pdf

Özcan, Abdullah, “Kur'an-1 Kerim'de Allah'in Sevdiği İnsan Tipleri”, Siirt Üniversitesi İlahiyat Fakültesi Dergisi, cilt 4, say1 2, 2017, "Görüntüleme”: http://dergipark.gov.tr/siirtilahiyat/issue/43339/ 527346

Özcan, Nezahat, "Nazım Hikmet'in Mona Lisa's1: Jokond ile Si-Ya-U”, Hacettepe Türkiyat Araştırmaları Dergisi, cilt 21, 2014, "Görüntüleme": 21 Nisan, 2019, https://docplayer.biz.tr/20018813-Nazim-hikmet-in-mona-lisa-si-jokondile-si-ya-u-nezahat-ozcan.html

Özuyar, Ali, "Türkiye'de Gösterilen İlk Filmler", Türk Sinema Araştırmalarl, 2014, "Görüntüleme": 20 Nisan, 2018, http://www.tsa.org.tr/tr/yazi/yazidetay/12/turkiye'de-gosterilen-ilk-filmler

Özön, Nijat, Türk Sinema Tarihi, 1. bs., İstanbul, Doruk, 1965.

Parla, Jale, Babalar ve Oğullar: Tanzimat Romanının Epistemolojik Kökenleri, 12. bs., İstanbul, İletişim, 2016.

Sefercioğlu, Nejat, "Divan Şiirinde Musiki ile İlgili Unsurların Kullanılışı", (T.Y.), "Görüntüleme": 21 Nisan, 2018, http://turkoloji.cu.edu.tr/ESKI TURK EDEBIYATI/nejat_sefercioglu_divan_siiri_musiki_unsurlar_kullanim.pdf 
Sontag, Susan, On Photography, 1. bs., New York, Rosetta, 2005.

Uludağ, Süleyman, “Ayna”, İslam Ansiklopedisi, İçinde, (T.Y.), "Görüntüleme": 22 Nisan, 2018, http://www.islamansiklopedisi.info/dia/maddesnc.php?MaddeAdi=ayna

Tanpınar, Ahmet Hamdi, Bütün Şiirleri, 21. bs., İstanbul, Dergah, 2011.

Yıldırım, Ece, "Türk Sinemasında Fotoğraf ve Sinema Arasındaki Teknik ve Estetik Tema İlişkileri” (Yayınlanmamış Yüksek Lisans Tezi), Mimar Sinan Üniversitesi, İstanbul, 2010, “Görüntüleme”: 13 Mayıs, 2018, https://tez.yok.gov.tr/ UlusalTezMerkezi/tezSorguSonucYeni.jsp

Yıldırım, Tunç, “Metin Erksan'ın Sevmek Zamanı Filminin Eleştirel Alımlaması", Global Media Journal, TR Edition, cilt 5, say1 9, 2014, "Görüntüleme": 24 Nisan, 2018, http://globalmediajournaltr. yeditepe.edu.tr/sites/default/files/Tunc, YILDIRIM .pdf

Yuva, Hümeyra, "Türk Şiirinde Zaman Temininin Değişimi”, Turkish Studies International Periodical for the Languages, Literature and History of Turkish or Turkic, 4, 2009, "Görüntüleme": 21 Nisan, 2018, http://turkoloji.cu.edu.tr/YENI TURK EDEBIYATI/humeyra_yuva_turk_siiri_zaman_temi.pdf 